\title{
Proficiency Testing
}

National Cancer Institute

\section{Source}

National Cancer Institute. Proficiency Testing. NCI Thesaurus. Code C99489.

A program for the determination of laboratory performance where individual labs perform the same test on the same or similar items or materials, with the results from each lab compared and evaluated. 